\author{
Xanthophylls의 급여가 계란 노른자의 착색 및 \\ 항산화성에 미치는 영향 \\ 민병진*이규호**.이성기* \\ 강원대학교 축산식품과학과*, 강원 대학교 사료생산공학과**
}

\title{
Effect of Dietary Xanthophylls Supplementation on Pigmentation and Antioxidant Properties in the Egg Yolks
}

\author{
B. J. Min*, K. H. Lee** and S. K. Lee* \\ Department of Food Science and Technology in Animal Resources, Kangwon National University* \\ Dept. of Animal Feed Science and Technology, Kangwon National University**
}

\begin{abstract}
This study was carried out to investigate the effects of dietary xanthophylls supplementation on pigmentation and antioxidant properties in the egg yolk. ISA Brown laying hens aged 50 weeks were fed five kinds of xanthophyll combination such as control(neither natural nor artificial xanthophylls in feed), T1(Commercial diet containing natural xanthopylls in grain + Lutein 10ppm + Capsantin 10ppm), T2(T1 + Capsanthin 65ppm), T3(T1 + Canthaxanthin 65ppm), T4(T1 + Capsanthin 10ppm + Canthaxanthin 65ppm), and T5(T1 + Capsanthin 65ppm + Canthaxanthin 10ppm). The $\mathrm{pH}$ values of all egg yolks were not significantly different during storage or feeding periods. CIE L*(lightness) values of T2 $\sim$ T5 egg yolks were lower than those of control and T1. Conversely, the CIE a*(redness) value of T2 $\sim \mathrm{T} 5$ egg yolks showed significantly higher $(\mathrm{P}<0.05)$. Egg yolk from chicks fed xanthophylls increased CIE $\mathrm{b}^{*}$ values. The CIE $\mathrm{b}^{*}$ (yellowness) values of $\mathrm{T} 2 \sim \mathrm{T} 5$ egg yolks were higher than control and $\mathrm{T} 1$ during storage at $37^{\circ} \mathrm{C}$ for 48 hours respectively. In the antioxidation experiment, dietary xanthophylls supplementation affected lipid antioxidation of egg yolk during storage. The TBARS(O.D.) of egg yolks from chicks fed xanthophylls were lower than that of control during incubation at $37^{\circ} \mathrm{C}$ or 10 hours. In conclusion, dietary xanthophylls supplementation influence to color difference and retardation of lipid oxidation in egg yolk.
\end{abstract}

(Key words : Xanthophylls, Egg yolk, Color, Antioxidant)

\section{I 서 론}

카로티노이드는 과일과 채소류에서 발견되는 대표적인 천연색소로 잘 알려져 왔다(Clark 등, 1999). 인간의 식이 중 과일과 야채는 식물에서 밝혀진 600 종 이상의 많은 카로티노이드 색소
를 함유한다. 식물에서 카로티노이드의 두 가 지 기능은 과잉의 빛 에너지를 안전하게 분해 시키고 세포막을 산화에 의한 손상으로부터 보 호하는 항산화 기능을 들 수가 있다. 자연계에 는 trans와 cis 형태의 카로티노이드가 모두 존 재할 수 있지만, 합성되어 만들어지는 카로티

\footnotetext{
Corresponding author : Sung Ki Lee, Department of Food Science and Technology in Animal Resources, Kangwon National University, Chunchon, 200-701, Korea. Tel : 033-250-8646, E-mail : skilee@ kangwon.ac.kr
} 
노이드는 대부분이 trans 형태이다(Yeum, 1996). 그러나 최근 들어 천연색소 및 이를 활 용한 합성물질들에 대한 연구가 늘어나면서 카 로티노이드는 색소기능이 다양해지고 있는 추 세이며, 여러 가지 질병을 예방하는 데에 응용 되고 있다.

난황색은 계란 또는 계란을 함유한 식품을 소비하는 소비자에게 있어 가장 중요한 품질의 하나로 인식되어 왔다(Strieff, 1970; El Boushy 와 Raterink, 1987). 왜냐하면 소비자들은 선호 하는 난황색의 계란을 구입하려고 하기 때문이 다(Sikder 등, 1998). 이러한 소비패턴의 변화에 적절히 대응하기 위한 좋은 해결책 중의 하나 로는 사료와 함께 색소를 첨가하여 인위적으로 난황색을 조절하는 방법을 들 수가 있다. 계란 난황의 착색은 유전적인 면도 있지만 한편으로 는 사료성분 및 빛에 의해 영향을 받기도 한다 (남, 2000). 난황의 노란색은 카로티노이드 색 소의 선택적인 축적에 기인한다(Balnave와 Bird, 1996). Canthaxanthin의 경우 난황의 착색 을 강화시키는데 사용되는 가장 일반적인 적색 카로티노이드로 잘 알려져 있다(Schiedt 등, 1987).

카로티노이드가 풍부한 식품의 섭취는 암 (Ziegler, 1991), 심장혈관질환(Gaziano와 Hennekens, 1993), 망막의 황반변성(Landrum와 Bone, 2001; Seddon 등, 1994) 위험의 감소에 관여하 고 있다는 보고가 있다. $\alpha-, \beta$-카로틴과 리코핀 등과 같은 hydrocarbon 카로티노이드는 폐나 피부, 소화기관과 관련된 암 발생율 감소에 관 계하며(Franceschi 등, 1994; Mayne 등, 1994; Murakoshi 등, 1992), lutein과 zeaxanthin과 같은 oxygenated 카로티노이드는 눈의 보호에 중요 하다는 보고(Yeum 등, 1995; Yeum, 1996)가 잇 따르고 있어 이를 뒷받침해 준다. Astaxanthin 함유 난황의 경구투여가 실험쥐의 전위암 발 생을 억제한다는 결과도 있다(이 등, 1997).

카로티노이드는 크게 카로틴과 크산토필로 구분되어 진다. 크산토필은 히드록시기를 가진 카로티노이드의 총칭으로 quenching singlet oxygen(Burton, 1989), trapping free radical 등의 작용을 가져 지질 과산화를 저해하며, 효과적
인 항산화제 역할을 하는 것으로 알려지고 있 다. 가금류는 카로티노이드를 합성하는 능력이 없어 사료를 통해 축적시키는 방법을 사용하고 있다(Balnave와 Bird, 1996). 지금까지 가금산업 에 있어서 크산토필의 주된 기능은 착색효과를 중심으로 연구되어져 왔으나(Bartov와 Bornstein, 1967; Brambila 등, 1963), 착색제 기능외에 새 로운 항산화 물질로써의 연구에 관심을 끌고 있다.

따라서 본 연구는 착색효과 및 항산화성이 있다고 알려진 천연 및 합성 크산토필을 사료 에 첨가했을 때 난황에 착색효과와 항산화 효 과를 가지는지 구명하고자 실시하였다.

\section{재료 및 방법}

\section{1. 시험사료}

본 시험에 이용된 사료의 배합율 및 성분함 량은 Table 1 과 같다. 본 시험에 대조구로 사용 된 사료는 사료내 크산토필이 전혀 함유되지 않도록 소맥과 대두박을 위주로 배합하였다. 시험구 사료는 옥수수와 corn gluten meal이 포 함되어 자연 크산토필이 함유된 일반 시판사료 를 이용하였다. 모든 시험사료는 대사에너지 $2,900 \mathrm{kcal}$, 사료 단백질 수준 $15.5 \%$ 로 고정하 여 이용하였다.

\section{2. 실험재료 및 설계}

시험동물은 50 주령의 갈색 산란계를 각 처리 수당 20수씩 3반복으로 총 300수를 2수용 3단 철제케이지에서 사육하여 시험을 수행하였다. 천연 및 합성 착색제의 첨가효과를 검토하기 위하여 대조구는 basal diet를 급여하였고, 처리 구는 자연 크산토필이 함유된 일반 시판사료 (Commercial diet containing natural xanthopylls in grain)에 각각의 착색제를 첨가 급여하였 다. 시험에 이용한 착색제는 천연 yellow 착 색제인 Lutein( $\beta, \varepsilon$-carotene-3,3'-diol, Kemin Co., Singapore), 천연 red 착색제인 Capsanthin 
Table 1. The formular and chemical composition of the experimental diet for the experiment

\begin{tabular}{|c|c|c|}
\hline Ingredient & $\begin{array}{l}\text { Basal } \\
\text { diet }^{3)}\end{array}$ & $\begin{array}{c}\text { Commercial } \\
\text { diet }^{4}\end{array}$ \\
\hline Yellow corn & - & 53.99 \\
\hline Wheat meal & 64.44 & - \\
\hline Wheat bran & - & 7.70 \\
\hline Soybean meal(CP 45\%) & 16.93 & 18.27 \\
\hline Corn gluten meal & - & 1.44 \\
\hline Corn germ meal & 5.00 & 5.00 \\
\hline Lard & 3.57 & 3.62 \\
\hline T.C.P & 1.89 & 1.76 \\
\hline Limestone & 7.33 & 7.38 \\
\hline $\mathrm{NaCl}$ (salt) & 0.20 & 0.20 \\
\hline Methionine & 0.21 & 0.19 \\
\hline Lysine-HCl & 0.03 & - \\
\hline L-Tryptophan & 0.01 & 0.06 \\
\hline Vitamin $^{1)}$ & 0.10 & 0.10 \\
\hline Mineral $^{2)}$ & 0.10 & 0.10 \\
\hline Choline-Cl & 0.09 & 0.09 \\
\hline Ronozyme & 0.10 & 0.10 \\
\hline Total & 100 & \\
\hline
\end{tabular}

\begin{tabular}{lcc}
\hline \multicolumn{3}{c}{ Chemical composition(\%) } \\
\hline \hline DM & 89.08 & 89.28 \\
Crude protein & 15.50 & 15.50 \\
ME(kcal/kg) & 2900 & 2900 \\
E.E. & 5.50 & 7.00 \\
Ca & 3.5 & 3.5 \\
P & 0.33 & 0.34 \\
Lys & 0.74 & 0.74 \\
Met+Cys & 0.64 & 0.62 \\
Thr & 0.56 & 0.58 \\
\hline
\end{tabular}

${ }^{1)}$ Provided per $\mathrm{kg}$ of complete diet : 9,000,000 IU vitamin A, 2,100,000 IU vitamin D3, 15,000 IU vitamin E.

${ }^{2)}$ Provided per $\mathrm{kg}$ of complete diet : 40,000 mg Fe, $3,500 \mathrm{mg} \mathrm{Cu}, 55,000 \mathrm{mg} \mathrm{Zn}, 50,000 \mathrm{mg} \mathrm{Mn}, 300$ mg Co, $600 \mathrm{mg}$ I, $130 \mathrm{mg}$ Se.

3) Basal diet contains neither natural nor artificial xanthophylls in feed.

4) Commercial diet contains natural xanthopylls in grain. (3.3'-dihydroxy- $\kappa$, $\kappa$-carotene-6'-one, Kemin Co., Singapore), 합성 Red 착색제인 Canthaxanthin( $\beta$, $\beta$-carotene-4,4'-dione, Roche., Swiss)을 사용하였 다. 시험구는 Table 2에서와 같이 기본사료 급 여구로 C(대조구)와 General diet에 T1(Lutein 10ppm + Capsanthin 10ppm), T2(T1 + Capsanthin 65ppm), T3(T1 + Canthaxanthin 65ppm), T4(T1 + Capsanthin 10ppm + Canthaxanthin 65ppm), T5(T1 + Capsanthin 65ppm + Canthaxanthin $10 \mathrm{ppm})$ 로 하여 각각의 착색제를 급여한지 7일, 14일, 21일, 28일된 산란계의 계란을 수거하여 각각 실험에 이용하였다.

Table 2. Experimental design

\begin{tabular}{|c|c|}
\hline Symbols & Treatments \\
\hline Control & Basal diet ${ }^{1)}$ \\
\hline $\mathrm{T} 1$ & $\begin{array}{l}\left.\text { Commercial } \operatorname{diet}^{2}\right)+ \text { Lutein 10ppm + } \\
\text { Capsanthin 10ppm }\end{array}$ \\
\hline $\mathrm{T} 2$ & T1 + Capsanthin 65ppm \\
\hline T3 & $\mathrm{T} 1$ + Canthaxanthin 65ppm \\
\hline $\mathrm{T} 4$ & $\begin{array}{c}\text { T1 + Capsanthin 10ppm + } \\
\text { Canthaxanthin 65ppm }\end{array}$ \\
\hline T5 & $\begin{array}{c}\mathrm{T} 1 \text { + Capsanthin 65ppm + } \\
\text { Canthaxanthin 10ppm }\end{array}$ \\
\hline
\end{tabular}

${ }^{1)}$ Basal diet contains neither natural nor artificial xanthophylls in feed.

2) Commercial diet contains natural xanthopylls in grain.

3. 계란의 수집 및 난황 처리

난황의 색깔측정과 항산화성을 시험하기 위하여 사양시험 기간 동안 각 주별로 농장 으로부터 1 시간 이내에 이송된 계란을 저온 실험실 $\left(4^{\circ} \mathrm{C}\right.$ ㅔㅓㅅㅓ 할란하여 난백은 버리고, 난 황만을 채취하였다. 시험구당 10 개의 난황을 잘 섞어 시험재료로 이용하였다. $\mathrm{pH}$ 와 색택 측정을 위해 난황 $59 \mathrm{~g}+0.01 \%$ sodium azide $1 \mathrm{ml}$ 비율로 삼각플라스크에 담아 균 질한 다음 shaking incubator에서 $37^{\circ} \mathrm{C}$. 조정 한 후 $1,500 \mathrm{rpm} / \mathrm{min}$ 의 속도로 5 분간 흔들어 준 후 사용하였다. 


\section{4. 실험방법}

(1) 난황 $\mathrm{pH}$ 및 색택 측정

$\mathrm{pH}$ 측정은 처리한 난황액 $10 \mathrm{~g}$ 에 증류수 100 $\mathrm{ml}$ 을 첨가하여 $10,000 \mathrm{rpm}$ 에서 60초간 homogenizer(AM-7, Nihonseiki, Kaisha, LTD)로 균질 화한 후 $\mathrm{pH}$ meter(F-12, Horiba, Japan)로 측정 하였다. 색택측정은 color difference meter (Yasuda Seiko Co, CR-300, Minolta, Japan)를 사용하여 난황액의 CIE L*(명도), $\mathrm{a}^{*}$ (적색도), $\mathrm{b*}$ *황색도)의 색택(CIE color value)을 측정하였 다. 색택의 측정에 사용된 표준판의 색도값은 $\mathrm{Y}=93.0, \mathrm{x}=0.3140, \mathrm{y}=0.3026$ 이었다. $\mathrm{pH}$ 와 색택 측정시간은 $0,12,24,36,48$ 시간으로 하였다.

\section{(2) 난황추출물 제조 및 리포좀을 이용한 산화 측정}

난황 $5 \mathrm{~g}$ 에 chloroform $45 \mathrm{ml}$ 을 가하여 5 분 간 흔들어 용해시킨 후 깔때기를 이용하여 (Whatman paper No. 4) 용액을 걸러주었으며, 걸러진 용액을 liposome 제조에 이용하였다. 리 포좀 모델 시스템의 이용은 Yin과 Faustman (1993)의 방법을 수정하여 실시하였다. 리포좀 의 제조는 추출용 수기에 phosphatidylcholine (PC, $30 \mathrm{mg}$ ), cholesterol (12 mg), dicetylphosphate (3 mg), 난황 추출물 $1 \mathrm{ml}$ 을 넣고, 최종 용량이 $5 \mathrm{ml}$ 이 되도록 chloroform : methanol(2:1)으로 채운 후, 잘 혼합되도록 수기를 흔들어준 다음 추출기의 욕조온도를 $40^{\circ} \mathrm{C}$ 맞추고 약 3-5분 간에 걸쳐 추출하였다. 추출된 수기에 glass bead를 넣고 질소가스를 주입한 다음 sodium phosphate buffer(pH7.2)를 넣고 암실에서 30분 간 흔들어 주고 30 분간 정치가 끝난 것을 항산 화 실험에 이용하였다. 각 처리구마다 산화제 $\mathrm{FeCl}_{2}(30 \mu \mathrm{M})$ 와 ascorbic $\operatorname{acid}(100 \mu \mathrm{M})$ 를 $200 \mu \mathrm{l}$ 씩 넣고 $37^{\circ} \mathrm{C}$ 서 교반시키면서 산화를 진행시 켰다. TBARS의 측정은 McDonald와 Hultin (1987)의 방법을 이용하였다.

(3) 통계처리

실험결과의 통계처리는 SAS program(SAS, 1995)을 이용하였으며, 각 실험군간의 유의성
검증을 위해 one-way ANOVA 방식을 사용하 였으며, 분산분석을 한 후 Duncan's multiple range test로 유의성 차이를 검증하였다.

\section{III 결과 및 고찰}

\section{1. 크산토필의 급여가 난황의 $\mathrm{pH}$ 및 색택에 미치는 영향}

본 논문에 표로 제시하지 않았지만, 크산토 필 첨가사료를 급여한 닭의 난황에서 $\mathrm{pH}$ 를 보 면 대조구(Control)와 모든 색소 첨가구간 유의 적인 차이를 보이지 않았다. 또한 $37^{\circ} \mathrm{C}$ 서 48 시간까지 저장하는 동안에도 난황의 $\mathrm{pH}$ 가 6.0 6.2 사이에 머물러 변화가 없는 것으로 나타났 으며, 사료급여 기간에 따른 차이도 역시 없었 다( $\mathrm{P}>0.05)$.

크산토필을 1 주 4주 동안 산란계에 급여 하고 채취한 계란의 난황색 $\mathrm{L}^{*}$ (명도) 값을 Table 3에 나타내고 있다. 급여 기간과 상관없 이 대조구과 $\mathrm{T} 1$ 의 $\mathrm{CIE} \mathrm{L*}$ 값이 저장 개시부터 48시간까지 T2 5 구에 비해 유의적으로 높 았다(I<0.05). 또한 대조구를 포함한 모든 처 리구에서 저장기간이 경과할수록 명도 값이 증 가하는 경향을 보였다.

크산토필을 급여한 닭의 난황에서 $\mathrm{a}^{*}$ (적색도) 값의 변화는 Table 4 와 같다. 4 주간 급여하였을 때 크산토필 종류와 농도에 따라 적색도 값이 다양하게 나타났다. 따라서 난황의 적색도가 여러 색깔 중에서 착색제에 따라 가장 영향을 많이 받는 것으로 나타났다. 색소가 함유되지 않은 대조구와 자연 색소가 함유된 일반 사료 에 $20 \mathrm{ppm}$ 의 천연 착색제를 첨가한 $\mathrm{T} 1$ 이 65 $\mathrm{ppm}$ 이상의 천연 또는 합성 착색제가 첨가된 $\mathrm{T} 2 \sim 5$ 구에 비해 적색도가 매우 낮았다(I< 0.05). 또한 대조구의 경우 급여기간과 상관없 이 저장기간 동안 지속적으로 낮은 적색도 값 을 나타내었다. 1 주간 급여하여 얻어진 난황의 저장 0시간 적색도 값은 $\mathrm{T} 2 \sim 5$ 구가 각각 21.8, 27.6, 27.7, 22.5이었고, 2주 급여 후 동일 한 시간에는 28.9, 32.3, 31.0, 34.5로 나타나 모 두 증가하는 경향을 나타내었다. 그러나 3 주와 
Table 3. Effect of dietary xanthophylls supplementation on CIE L*(Lightness) value in egg yolk during storage at $37^{\circ} \mathrm{C}$ or 48 hours

\begin{tabular}{|c|c|c|c|c|c|c|c|}
\hline & \multirow{2}{*}{$\begin{array}{c}\text { Feeding } \\
\text { Period(Wks) }\end{array}$} & \multirow{2}{*}{ Treatments ${ }^{2)}$} & \multicolumn{5}{|c|}{ Oxidation Time(hrs) } \\
\hline & & & 0 & 12 & 24 & 36 & 48 \\
\hline \multirow{24}{*}{$\mathrm{L}^{*}$} & \multirow{6}{*}{1} & Control & $57.3 \pm 1.2^{\mathrm{aB} 1)}$ & $60.5 \pm 1.1^{\mathrm{aA}}$ & $59.6 \pm 0.9^{\mathrm{aA}}$ & $59.5 \pm 0.6^{\mathrm{aA}}$ & $59.3 \pm 1.6^{\mathrm{aA}}$ \\
\hline & & $\mathrm{T} 1$ & $54.9 \pm 3.0^{\mathrm{aB}}$ & $59.2 \pm 0.4^{\mathrm{aA}}$ & $57.5 \pm 1.9^{\mathrm{aAB}}$ & $56.2 \pm 0.6^{\mathrm{bAB}}$ & $57.3 \pm 2.8^{\mathrm{aAB}}$ \\
\hline & & $\mathrm{T} 2$ & $43.0 \pm 3.5^{\mathrm{bC}}$ & $47.2 \pm 1.0^{\mathrm{bAB}}$ & $44.3 \pm 1.3^{\mathrm{bcBC}}$ & $45.7 \pm 1.2^{\mathrm{dABC}}$ & $48.6 \pm 2.9^{\mathrm{cA}}$ \\
\hline & & T3 & $44.3 \pm 1.3^{\mathrm{bB}}$ & $45.0 \pm 2.4^{\mathrm{cB}}$ & $45.9 \pm 3.2^{\mathrm{bB}}$ & $43.5 \pm 1.8^{\mathrm{eB}}$ & $52.9 \pm 3.5^{\mathrm{bA}}$ \\
\hline & & $\mathrm{T} 4$ & $44.6 \pm 2.3^{\mathrm{bB}}$ & $48.3 \pm 1.4^{\mathrm{bA}}$ & $42.1 \pm 1.2^{\mathrm{cB}}$ & $50.2 \pm 1.6^{\mathrm{cA}}$ & $48.8 \pm 2.5^{\mathrm{bcA}}$ \\
\hline & & $\mathrm{T} 5$ & $45.0 \pm 2.1^{\mathrm{bBC}}$ & $43.2 \pm 1.5^{\mathrm{cC}}$ & $44.4 \pm 0.4^{\mathrm{bcBC}}$ & $46.1 \pm 0.8^{\mathrm{dB}}$ & $49.6 \pm 2.4^{\mathrm{bcA}}$ \\
\hline & \multirow{6}{*}{2} & Control & $61.0 \pm 1.9^{\mathrm{aB}}$ & $65.4 \pm 1.1^{\mathrm{aAB}}$ & $61.2 \pm 4.3^{\mathrm{aB}}$ & $66.8 \pm 4.4^{\mathrm{aA}}$ & $64.7 \pm 2.1^{\mathrm{aAB}}$ \\
\hline & & $\mathrm{T} 1$ & $56.1 \pm 1.2^{\mathrm{bC}}$ & $60.8 \pm 1.5^{\mathrm{bAB}}$ & $57.9 \pm 3.3^{\mathrm{aBC}}$ & $60.7 \pm 3.5^{\mathrm{bAB}}$ & $62.5 \pm 2.5^{\mathrm{aA}}$ \\
\hline & & $\mathrm{T} 2$ & $39.3 \pm 4.5^{\mathrm{dC}}$ & $41.5 \pm 1.4^{\mathrm{cBC}}$ & $46.2 \pm 3.2^{\mathrm{bA}}$ & $45.5 \pm 1.4^{\mathrm{cAB}}$ & $45.4 \pm 0.4^{\mathrm{bcAB}}$ \\
\hline & & T3 & $40.2 \pm 4.3^{\mathrm{dB}}$ & $38.0 \pm 2.5^{\mathrm{dB}}$ & $41.7 \pm 2.4^{\mathrm{bB}}$ & $46.6 \pm 2.5^{\mathrm{cA}}$ & $46.5 \pm 2.9^{\mathrm{bcA}}$ \\
\hline & & $\mathrm{T} 4$ & $45.3 \pm 3.4^{\mathrm{cAB}}$ & $40.3 \pm 0.4^{\mathrm{cdC}}$ & $43.7 \pm 3.4^{\mathrm{bBC}}$ & $45.5 \pm 3.2^{\mathrm{cAB}}$ & $48.4 \pm 1.9^{\mathrm{bA}}$ \\
\hline & & $\mathrm{T} 5$ & $42.3 \pm 2.3^{\mathrm{cdB}}$ & $38.0 \pm 2.4^{\mathrm{dC}}$ & $41.9 \pm 0.4^{\mathrm{bB}}$ & $44.3 \pm 1.2^{\mathrm{cAB}}$ & $45.2 \pm 0.8^{\mathrm{cA}}$ \\
\hline & \multirow{6}{*}{3} & Control & $56.9 \pm 3.0^{\mathrm{aB}}$ & $60.8 \pm 3.3^{\mathrm{aB}}$ & $60.6 \pm 3.1^{\mathrm{aB}}$ & $59.5 \pm 1.7^{\mathrm{aB}}$ & $66.2 \pm 4.0^{\mathrm{aA}}$ \\
\hline & & $\mathrm{T} 1$ & $52.0 \pm 3.1^{\mathrm{bB}}$ & $59.8 \pm 2.3^{\mathrm{aA}}$ & $60.2 \pm 3.1^{\mathrm{aA}}$ & $58.2 \pm 3.4^{\mathrm{aA}}$ & $60.1 \pm 3.2^{\mathrm{bA}}$ \\
\hline & & $\mathrm{T} 2$ & $37.4 \pm 0.6^{\mathrm{dC}}$ & $46.2 \pm 2.7^{\mathrm{bA}}$ & $43.8 \pm 4.9^{\mathrm{bAB}}$ & $41.8 \pm 1.0^{\mathrm{cB}}$ & $44.2 \pm 0.9^{\mathrm{cAB}}$ \\
\hline & & T3 & $40.6 \pm 3.7^{\mathrm{cdAB}}$ & $37.8 \pm 0.8^{\mathrm{cB}}$ & $41.2 \pm 2.1^{\mathrm{bAB}}$ & $41.5 \pm 3.0^{\mathrm{cAB}}$ & $41.8 \pm 1.0^{\mathrm{cdA}}$ \\
\hline & & $\mathrm{T} 4$ & $42.9 \pm 3.4^{\mathrm{cAB}}$ & $44.6 \pm 2.4^{\mathrm{bA}}$ & $43.6 \pm 3.8^{\mathrm{bAB}}$ & $43.6 \pm 3.8^{\mathrm{bcAB}}$ & $39.5 \pm 0.3^{\mathrm{dB}}$ \\
\hline & & T5 & $40.6 \pm 3.4^{\mathrm{cdB}}$ & $43.7 \pm 2.0^{\mathrm{bAB}}$ & $45.2 \pm 2.0^{\mathrm{bA}}$ & $45.8 \pm 1.2^{\mathrm{bA}}$ & $43.5 \pm 1.0^{\mathrm{cAB}}$ \\
\hline & \multirow{6}{*}{4} & Control & $54.9 \pm 2.4^{\mathrm{aC}}$ & $58.1 \pm 1.2^{\mathrm{aB}}$ & $58.7 \pm 0.6^{\mathrm{aB}}$ & $64.4 \pm 1.7^{\mathrm{aA}}$ & $64.6 \pm 1.7^{\mathrm{aA}}$ \\
\hline & & $\mathrm{T} 1$ & $49.9 \pm 0.5^{\mathrm{bE}}$ & $52.9 \pm 0.8^{\mathrm{bD}}$ & $55.1 \pm 1.5^{\mathrm{bC}}$ & $61.9 \pm 1.5^{\mathrm{aA}}$ & $59.3 \pm 1.9^{\mathrm{bB}}$ \\
\hline & & $\mathrm{T} 2$ & $36.7 \pm 1.2^{\mathrm{dB}}$ & $37.6 \pm 0.8^{\mathrm{dB}}$ & $44.5 \pm 2.1^{\mathrm{cA}}$ & $45.7 \pm 3.8^{\mathrm{bA}}$ & $44.7 \pm 2.2^{\mathrm{cA}}$ \\
\hline & & T3 & $39.1 \pm 1.2^{\mathrm{cdB}}$ & $34.7 \pm 2.2^{\mathrm{eC}}$ & $38.0 \pm 2.4^{\mathrm{eB}}$ & $42.4 \pm 0.6^{\mathrm{cA}}$ & $43.9 \pm 1.4^{\mathrm{cA}}$ \\
\hline & & $\mathrm{T} 4$ & $37.8 \pm 2.7^{\mathrm{dC}}$ & $35.9 \pm 0.4^{\mathrm{deC}}$ & $41.7 \pm 1.9^{\mathrm{dB}}$ & $46.1 \pm 2.3^{\mathrm{bA}}$ & $42.5 \pm 1.1^{\mathrm{cB}}$ \\
\hline & & T5 & $42.0 \pm 3.4^{\mathrm{cAB}}$ & $40.5 \pm 2.7^{\mathrm{cB}}$ & $45.0 \pm 1.0^{\mathrm{cA}}$ & $43.3 \pm 0.8^{\mathrm{bcAB}}$ & $44.1 \pm 1.0^{\mathrm{cA}}$ \\
\hline
\end{tabular}

1)abcde Means within column with different superscripts are significantly different $(\mathrm{I}<0.05)$.

${ }^{A B C D}$ Means within row with different superscripts are significantly different $(I<0.05)$.

${ }^{2)}$ Control : No pigment.

$\mathrm{T} 1$ : Commercial diet + Lutein 10ppm + Capsanthin 10ppm.

T2 : T1 + Capsanthin 65ppm(Natural red).

T3 : T1 + Canthaxanthin 65ppm(Synthetic red).

T4 : T1 + Capsanthin 10ppm(Natural red) + Canthaxanthin 65ppm(Synthetic red).

$\mathrm{T} 5$ : T1 + Capsanthin 65ppm(Natural red) + Canthaxanthin 10ppm(Synthetic red).

4주에는 별다른 차이를 보이지 않았다. 이러한 결과는 사료에 착색제를 급여하면 급여 2주까 지는 난황으로 적색 계통의 색소 유입이 증가 하지만, 그 이후에는 증가하지 않았음을 시사 하고 있다. 적색 착색제의 경우 합성 착색제인 canthaxanthin이 $65 \mathrm{ppm}$ 첨가된 $\mathrm{T} 3$ 와 $\mathrm{T} 4$ 구가 다른 처리구에 비해서 가장 높은 적색도를 나 타내었다. 그러므로 적색색소로 2주 정도 급여
하면 난황의 적색착색 효과를 얻는데 충분하다 고 사료된다. 급여 기간 내내 가장 많은 함량 의 착색제가 급여된 $\mathrm{T} 4$ 와 $\mathrm{T} 5$ 의 적색도 값이 $\mathrm{T} 2$ 와 $\mathrm{T} 3$ 보다 높지 않고 비슷한 수준을 유지하 였다. 이것은 처리구 모두에 천연 황색 착색제 $10 \mathrm{ppm}$ 이 첨가되었기 때문에 적색의 침적을 방해하였거나, 또는 적정수준보다 높게 급여하 여도 더 이상 적색도는 증대될 수 없는 것으로 
Table 4. Effect of dietary xanthophylls supplementation on CIE $a^{\star}$ (Redness) value in egg yolk during storage at $37^{\circ} \mathrm{C}$ or 48 hours

\begin{tabular}{|c|c|c|c|c|c|c|c|}
\hline & \multirow{2}{*}{$\begin{array}{c}\text { Feeding } \\
\text { Period(Wks) }\end{array}$} & \multirow{2}{*}{ Treatments } & \multicolumn{5}{|c|}{ Storage Time(hrs) } \\
\hline & & & 0 & 12 & 24 & 36 & 48 \\
\hline \multirow{24}{*}{$\mathrm{a}^{*}$} & \multirow{6}{*}{1} & Control & $-6.5 \pm 0.2^{\mathrm{dA} 1)}$ & $-7.1 \pm 0.4^{\mathrm{dB}}$ & $-7.2 \pm 0.2^{\mathrm{dB}}$ & $-6.9 \pm 0.2^{\mathrm{fB}}$ & $-6.9 \pm 0.1^{\mathrm{eB}}$ \\
\hline & & $\mathrm{T} 1$ & $-1.5 \pm 0.7^{\mathrm{cB}}$ & $-1.9 \pm 0.2^{\mathrm{cB}}$ & $-0.8 \pm 1.1^{\mathrm{cB}}$ & $-3.2 \pm 1.3^{\mathrm{eC}}$ & $0.7 \pm 0.4^{\mathrm{dA}}$ \\
\hline & & $\mathrm{T} 2$ & $21.8 \pm 3.1^{\mathrm{bB}}$ & $21.1 \pm 1.4^{\mathrm{abB}}$ & $24.2 \pm 4.1^{\mathrm{bA}}$ & $25.6 \pm 0.8^{\mathrm{cA}}$ & $25.5 \pm 0.9^{\mathrm{cA}}$ \\
\hline & & T3 & $27.6 \pm 4.0^{\mathrm{aBC}}$ & $24.2 \pm 3.5^{\mathrm{aC}}$ & $33.4 \pm 3.2^{\mathrm{aA}}$ & $31.4 \pm 1.2^{\mathrm{bAB}}$ & $34.5 \pm 2.1^{\mathrm{bA}}$ \\
\hline & & $\mathrm{T} 4$ & $27.7 \pm 4.5^{\mathrm{aB}}$ & $23.3 \pm 3.5^{\mathrm{abB}}$ & $24.9 \pm 1.7^{\mathrm{bB}}$ & $33.9 \pm 2.1^{\mathrm{aA}}$ & $38.2 \pm 3.9^{\mathrm{aA}}$ \\
\hline & & $\mathrm{T} 5$ & $22.5 \pm 1.4^{\mathrm{bC}}$ & $19.7 \pm 2.8^{\mathrm{bBC}}$ & $22.8 \pm 4.0^{\mathrm{bA}}$ & $22.8 \pm 3.0^{\mathrm{dB}}$ & $23.9 \pm 1.1^{\mathrm{cA}}$ \\
\hline & \multirow{6}{*}{2} & Control & $-7.5 \pm 0.1^{\mathrm{dA}}$ & $-7.5 \pm 0.2^{\mathrm{eA}}$ & $-8.9 \pm 0.3^{\mathrm{dB}}$ & $-8.6 \pm 0.6^{\mathrm{dB}}$ & $-9.0 \pm 0.2^{\mathrm{eB}}$ \\
\hline & & $\mathrm{T} 1$ & $2.0 \pm 0.4^{\mathrm{cA}}$ & $2.6 \pm 0.4^{\mathrm{dA}}$ & $-0.6 \pm 1.6^{\mathrm{cB}}$ & $-1.2 \pm 0.7^{\mathrm{cB}}$ & $-0.2 \pm 1.2^{\mathrm{dB}}$ \\
\hline & & $\mathrm{T} 2$ & $28.9 \pm 3.9^{\mathrm{bA}}$ & $24.4 \pm 2.4^{\mathrm{cAB}}$ & $23.6 \pm 4.2^{\mathrm{bB}}$ & $20.5 \pm 1.8^{\mathrm{bB}}$ & $20.6 \pm 3.2^{\mathrm{cB}}$ \\
\hline & & T3 & $32.3 \pm 2.0^{\mathrm{abA}}$ & $31.8 \pm 1.8^{\mathrm{aA}}$ & $33.4 \pm 2.1^{\mathrm{aA}}$ & $28.9 \pm 3.8^{\mathrm{aA}}$ & $28.7 \pm 4.4^{\mathrm{bA}}$ \\
\hline & & $\mathrm{T} 4$ & $31.0 \pm 2.3^{\mathrm{bB}}$ & $31.7 \pm 1.9^{\mathrm{aB}}$ & $32.5 \pm 1.7^{\mathrm{aB}}$ & $31.9 \pm 2.6^{\mathrm{aB}}$ & $35.0 \pm 0.9^{\mathrm{aA}}$ \\
\hline & & T5 & $34.5 \pm 2.3^{\mathrm{aA}}$ & $27.5 \pm 1.2^{\mathrm{bB}}$ & $21.9 \pm 2.4^{\mathrm{bC}}$ & $21.6 \pm 2.4^{\mathrm{bC}}$ & $22.2 \pm 3.0^{\mathrm{cC}}$ \\
\hline & \multirow{6}{*}{3} & Control & $-8.3 \pm 0.4^{\mathrm{dA}}$ & $-8.2 \pm 0.2^{\mathrm{dA}}$ & $-9.2 \pm 0.3^{\mathrm{dB}}$ & $-8.4 \pm 0.3^{\mathrm{dA}}$ & $-9.2 \pm 0.3^{\mathrm{dB}}$ \\
\hline & & $\mathrm{T} 1$ & $-0.1 \pm 0.5^{\mathrm{cB}}$ & $1.6 \pm 1.0^{\mathrm{cA}}$ & $-0.1 \pm 0.8^{\mathrm{cB}}$ & $-0.4 \pm 0.8^{\mathrm{cB}}$ & $-3.0 \pm 0.7^{\mathrm{cC}}$ \\
\hline & & $\mathrm{T} 2$ & $29.8 \pm 1.1^{\mathrm{bAB}}$ & $31.8 \pm 2.9^{\mathrm{aA}}$ & $28.0 \pm 2.2^{\mathrm{bBC}}$ & $27.4 \pm 1.2^{\mathrm{bBC}}$ & $24.9 \pm 2.3^{\mathrm{bC}}$ \\
\hline & & T3 & $31.9 \pm 1.0^{\mathrm{abAB}}$ & $33.1 \pm 2.4^{\mathrm{aA}}$ & $33.2 \pm 1.7^{\mathrm{aA}}$ & $33.6 \pm 1.2^{\mathrm{aA}}$ & $30.0 \pm 1.7^{\mathrm{aB}}$ \\
\hline & & $\mathrm{T} 4$ & $33.4 \pm 3.2^{\mathrm{aB}}$ & $34.8 \pm 1.0^{\mathrm{aB}}$ & $34.0 \pm 1.4^{\mathrm{aB}}$ & $34.0 \pm 1.4^{\mathrm{aB}}$ & $29.3 \pm 1.3^{\mathrm{aA}}$ \\
\hline & & $\mathrm{T} 5$ & $29.8 \pm 0.7^{\mathrm{bA}}$ & $24.8 \pm 3.9^{\mathrm{bC}}$ & $29.1 \pm 0.8^{\mathrm{bAB}}$ & $28.7 \pm 1.1^{\mathrm{bAB}}$ & $26.4 \pm 1.2^{\mathrm{bBC}}$ \\
\hline & \multirow{6}{*}{4} & Control & $-8.7 \pm 0.5^{\mathrm{eA}}$ & $-9.6 \pm 0.4^{\mathrm{dB}}$ & $-10.1 \pm 0.2^{\mathrm{dC}}$ & $-11.0 \pm 0.1^{\mathrm{dD}}$ & $-10.7 \pm 0.1^{\mathrm{dD}}$ \\
\hline & & $\mathrm{T} 1$ & $1.4 \pm 0.1^{\mathrm{dA}}$ & $-1.7 \pm 0.2^{\mathrm{cBC}}$ & $-3.2 \pm 0.6^{\mathrm{cC}}$ & $-2.3 \pm 0.4^{\mathrm{cBC}}$ & $-0.7 \pm 3.2^{\mathrm{cAB}}$ \\
\hline & & $\mathrm{T} 2$ & $27.4 \pm 1.4^{\mathrm{cA}}$ & $28.2 \pm 1.0^{\mathrm{bA}}$ & $26.0 \pm 2.3^{\mathrm{bA}}$ & $28.5 \pm 1.8^{\mathrm{aA}}$ & $22.4 \pm 1.3^{\mathrm{bB}}$ \\
\hline & & T3 & $33.2 \pm 1.9^{\mathrm{aA}}$ & $31.6 \pm 1.0^{\mathrm{aAB}}$ & $32.2 \pm 0.8^{\mathrm{aAB}}$ & $30.2 \pm 1.3^{\mathrm{aB}}$ & $30.7 \pm 3.1^{\mathrm{aAB}}$ \\
\hline & & $\mathrm{T} 4$ & $30.8 \pm 2.2^{\mathrm{abB}}$ & $31.1 \pm 1.5^{\mathrm{aB}}$ & $31.7 \pm 1.3^{\mathrm{aB}}$ & $30.5 \pm 1.1^{\mathrm{aB}}$ & $30.5 \pm 1.7^{\mathrm{aA}}$ \\
\hline & & T5 & $28.3 \pm 3.6^{\mathrm{bcA}}$ & $27.7 \pm 1.5^{\mathrm{bA}}$ & $26.1 \pm 5.6^{\mathrm{bA}}$ & $26.0 \pm 2.2^{\mathrm{bA}}$ & $28.7 \pm 0.6^{\mathrm{aA}}$ \\
\hline
\end{tabular}

1) abcdef Means within column with different superscripts are significantly different $(I<0.05)$.

${ }^{A B C D}$ Means within row with different superscripts are significantly different $(\mathrm{I}<0.05)$.

사료된다.

Table 5는 대조구와 크산토필을 급여한 산란 계로부터 얻어진 난황에서 $\mathrm{b} *$ (황색도)값의 변 화를 나타낸 것이다. 저장 48시간까지 $\mathrm{T} 1$ 구가 대조구와 $\mathrm{T} 2 \sim 5$ 구 보다 황색도가 높았다. 이 것은 황색 크산토필(Lutein)이 $10 \mathrm{ppm}$ 함유된 $\mathrm{T} 1$ 이 여기에 $65 \mathrm{ppm}$ 의 고농도 적색 크산토필을 첨가한 $\mathrm{T} 2 \sim 5$ 구나, 크산토필이 함유되지 않은 대조구에 비해 황색 색깔이 더 많이 발현되었 으리라 사료된다. 대조구도 색소가 전혀 첨가 되지 않은 사료로 급여한 난황이기 때문에 저 장시간 내내 천연 및 합성 첨가구에 비해 뚜렷
하게 낮은 황색도 값을 보여주었다(I<0.05).

사료를 통한 난황색소의 침적은 크산토필의 종류와 첨가량에 따라 색깔에 직접적으로 관여한 다는 사실이 잘 알려져 있다(Bartov와 Bornstein, 1967; Fletcher와 Halloran, 1981; Balnave와 Bird; 1996). 총괄적으로 크산토필 급여로 인한 난황색의 변화를 살펴보면, 착색제의 첨가가 난황의 명도를 떨어뜨리는 결과를 보였으며, 적색색소의 첨가량이 많으면 적색도가 크게 향 상했으나, 천연 및 합성 색소를 함께 첨가한 경우에 비슷한 수준을 보여 추가적인 상승효과 는 보이질 않았다. Storebakken와 $\mathrm{No}(1992)$ 는 
Table 5. Effect of dietary xanthophylls supplementation on CIE b*(Yellowness) value in egg yolk during storage at $37^{\circ} \mathrm{C}$ or 48 hours

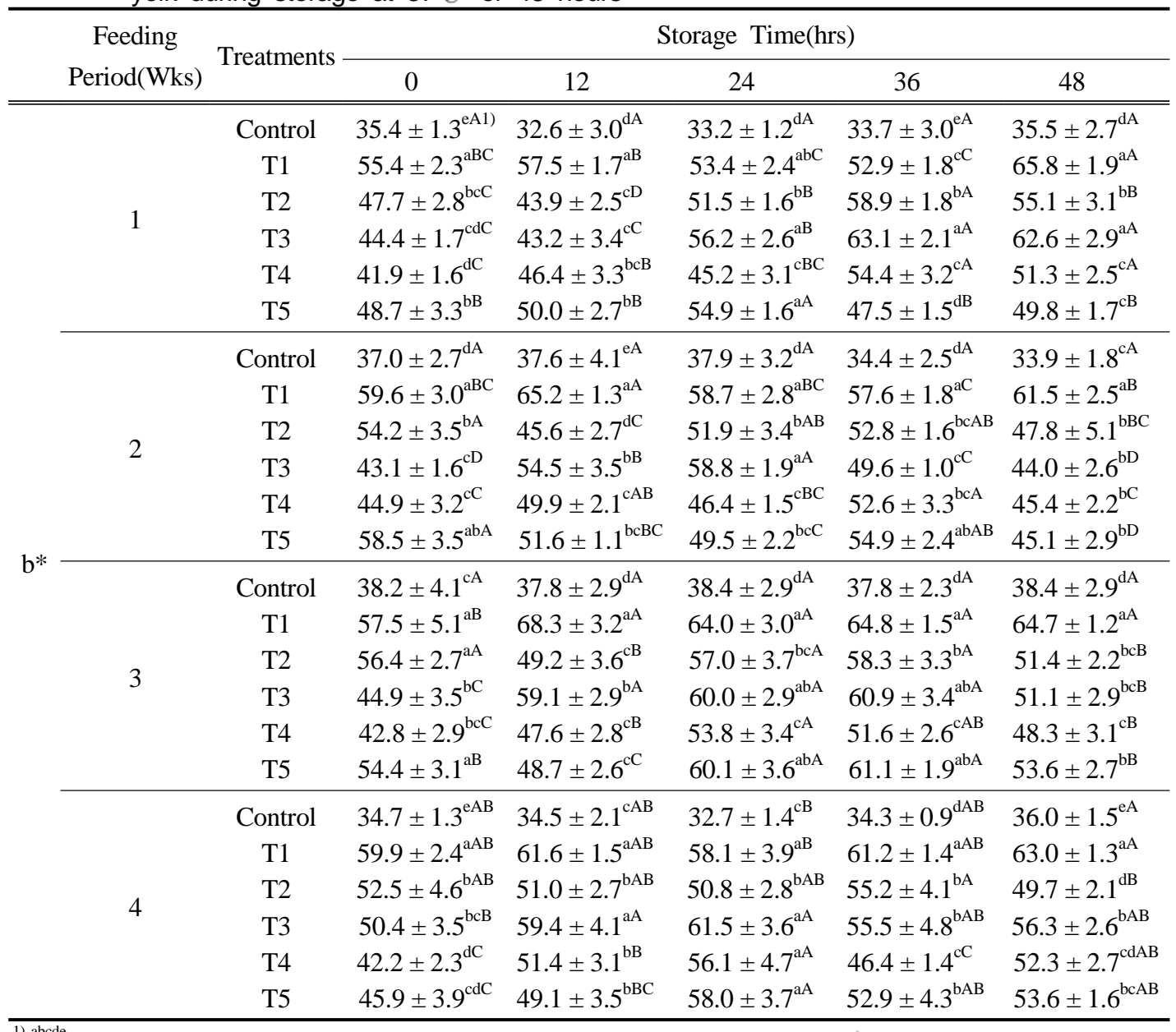

1) abcde Means within column with different superscripts are significantly different $(I<0.05)$.

${ }^{A B C D}$ Means within row with different superscripts are significantly different $(I<0.05)$.

카로티노이드 농도를 $50 \mathrm{mg} / \mathrm{kg}$ 수준 이상으로 급여하였을 때 색소침착에 있어서 유의적인 증 가를 보이지 않았다고 하였다. 황색도의 경우 에서도 적색도와 마찬가지로 적색 색소가 가장 적게 첨가된 $\mathrm{T} 1$ 의 값이 가장 높은 황색도를 보여주었으며, 색소의 첨가가 전혀 되지 않은 대조구의 값이 가장 낮았고, 급여기간에 대한 변화는 크지 않음을 알 수 있었다. 이것은 반 대로 급여기간이 비교적 짧아도 색소에 의한 색택의 변화에 충분히 기여할 수 있다는 것을 의미한다. 따라서 색택의 목적만을 위해 사료 에 색소를 첨가하고자 한다면 1 주 정도의 사양만으로도 원하는 착색효과를 거둘 수 있다
고 사료된다. 다만 아쉬운 점은 본 실험에서는 첨가량을 세분화하여 실험하지 못하였기 때문 에 착색을 위한 가장 적합한 첨가량의 제시를 할 수 없었다.

\section{2. 크산토필의 급여가 난황의 항산화에 미치 는 영향}

크산토필을 급여하여 생산한 난황의 저장중 지방산화 안정성을 구명하기 위하여 리포좀을 제조하여 인위적인 산화를 진행시켰다. 저장 0시간에는 TBARS(O.D.)값이 약 0.1로서 처리 구간 차이를 보이지 않았지만, 산화시간이 
1 Week

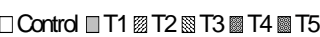

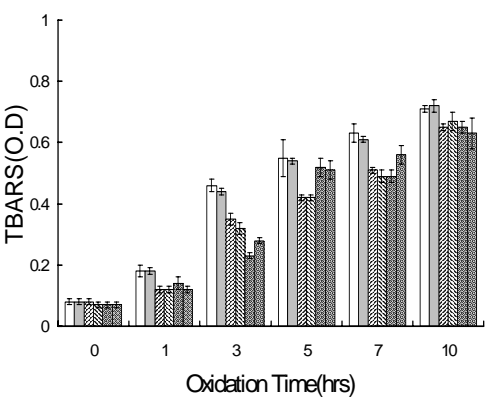

3 Weeks

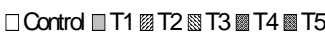

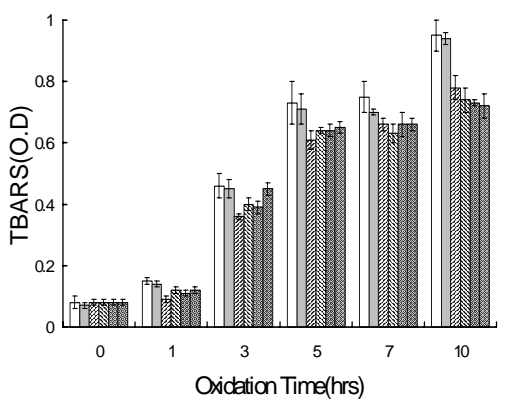

2 Weeks

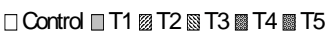

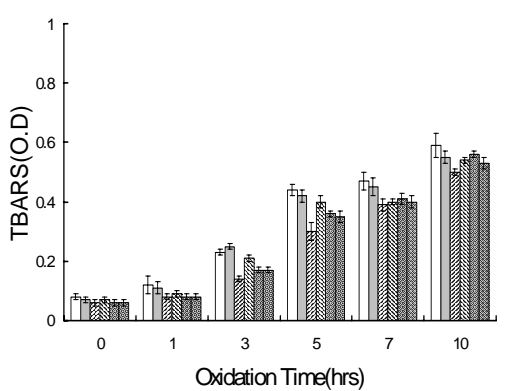

4 Weeks

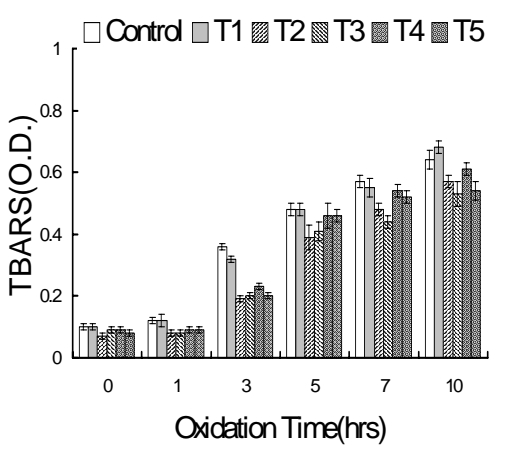

Fig. 1. TBARS(O.D.) of egg yolk during oxidation at $37^{\circ} \mathrm{C}$ or 10 hours.

길어짐에 따라 지속적으로 증가하는 경향을 나 타내었다 $(\mathrm{I}<0.05)$. 크산토필을 급여하지 않은 대조구의 경우 저장 기간동안 $\mathrm{T} 1$ 을 제외한 모 든 착색제 첨가구에 비하여 가장 높은 흡광도 를 나타내었다. 대조구와 $\mathrm{T} 1$ 구는 저장기간 내내 대체적으로 높은 흡광도를 나타내어 크 산토필 첨가량이 많은 $\mathrm{T} 2 \sim 5$ 구에 비해 난황 의 산화가 잘 일어남을 알 수 있었다. 일반사 료에 천연 색소의 첨가량이 적은 $\mathrm{T} 1(20 \mathrm{ppm})$ 구는 대조구에 비해 항산화성이 나타나지 않 거나 산화 10 시간의 흡광도가 대조구보다 높 은 경우가 있었다. 따라서 대조구와 $\mathrm{T} 1$ 구는 항산화 효과가 없는 것으로 나타났다. 반면 산 화 10 시간동안 $\mathrm{T} 2 \sim 5$ 구는 대조구와 $\mathrm{T} 1$ 에 비해 항산화력을 유지하였다. 이것은 천연 및 합성 착색제의 첨가로 인하여 착색제가 가지
고 있는 항산화 성분이 닭의 난황내로 전해져 지질산화를 지연시키는 것으로 생각되며, 또한 크산토필을 고농도로 첨가할수록 보다 좋은 항산화 효과가 있음을 보여주고 있다. Clark (1999) 등은 리포좀 모델 시스템에서 canthaxanthin이 $5 \mu \mathrm{M}$ 과 $10 \mu \mathrm{M}$ 의 농도 모두에서 항산 화 효과가 있다고 보고하였다. 이처럼 합성 색 소인 canthaxanthin은 적은 양으로도 항산화 효 과를 가진다는 것을 알 수가 있다. 그러나 본 실험에서는 색소의 혼합 첨가량 합계가 $20 \mathrm{ppm}(\mathrm{T} 1)$ 인 경우 항산화성이 매우 적었고, 저장시간이 경과하면서 대조구에 비해 오히려 떨어지는 경우도 있었기 때문에 유의차가 없 는 것으로 나타났다 $(\mathrm{P}>05)$. 이것은 사료를 통해서 섭취되기 때문에 실제로 몸 안에 축적 되거나 또는 난황으로 전이되는 과정에서 손 
실이 발생하였으리라 사료된다. 또한 천연 및 합성착색제 단독 비교에 있어서도 어느 쪽이 더 우수한 항산화성을 지녔는지에 대한 정확 한 결론을 도출하기 위해서는 추가 연구가 필 요하다.

\section{IV 요 약}

크산토필의 첨가 급여가 계란의 난황에서 착 색과 항산화 효과에 미치는 영향을 구명하기 위하여 본 실험을 실시하였다. 사료 속에 어떠 한 색소도 함유되지 않은 것을 대조구(기본 사 료)로 하고, 옥수수와 corn gluten meal이 들어 있어 자연 크산토필이 함유된 일반 시판사료를 시험구의 사료로 이용하였다. 50 주령의 갈색 산 란계를 이용하여 4주간 사양시험을 실시하였다. 시험구로는 $\mathrm{T} 1$ (일반 시판사료 + lutein $10 \mathrm{ppm}+$ capsanthin 10ppm), T2(T1 + capsanthin 65ppm), T3 (T1 + canthaxanthin 65ppm), T4(T1 + capsanthin 10ppm + canthaxanthin 65ppm), T5(T1 + capsanthin $65 \mathrm{ppm}+$ canthaxanthin 10ppm)로 나누어 시험 을 수행하였다. 난황의 $\mathrm{pH}$ 는 처리구간 유의적 인 차이를 보이지 않았다. 착색 실험으로 $37^{\circ} \mathrm{C}$ 에서 48시간까지 저장하는 동안 $\mathrm{T} 2 \sim 5$ 구의 명도 $\left(\mathrm{L}^{*}\right)$ 가 대조구 또는 $\mathrm{T} 1$ 에 비해 낮았고, 적 색도 $\left(\mathrm{a}^{*}\right)$ 는 더 높았다 $(\mathrm{I}<0.05)$. 또한 $\mathrm{T} 2 \sim 5$ 구의 황색도 $\left(\mathrm{b}^{*}\right)$ 는 $\mathrm{T} 1$ 에 비해 낮은 값을 보였 다. 리포좀 모델시스템에서 산화기간 동안 $\mathrm{T}$ 1 5 구가 대조구에 비해 TBARS(O.D.)가 더 낮았고, 급여농도가 높은 $\mathrm{T} 2 \sim 5$ 구가 $\mathrm{T} 1$ 보다 더 낮았다 $(\mathrm{P}<0.05)$. 결론적으로 산란계 사료에 lutein, capsanthin, canthaxanthin을 혼합 급여하 면 종류와 농도에 따라 난황의 착색에 영향을 미칠 뿐만 아니라 난황의 산화도 지연시킨다는 것을 알 수 있었다.

(색인어 : 크산토필, 난황, 색택, 항산화)

$$
\mathrm{V} \text { 사 사 }
$$

본 연구는 2000년도 한국과학재단(R01-2000000-00209-0) 과제로 수행된 연구결과의 일부이 며 이에 감사를 드립니다.

\section{$\mathrm{VI}$ 인 용 문 헌}

1. Balnave, D. and Bird, J. N. 1996. Relative efficiencies of yellow carotenoids for egg yolk pigmentation. AJAS. 9:515.

2. Bartov, I. and Bornstein, S. 1967. Studies on egg yolk pigmentation. Poult. Sci. 46: 797.

3. Brambila, S. J., Pino, J. A. and Mendoza, C. 1963. Studies with a natural source of xanthophylls for the pigmentation of egg yolks and skin of poultry. Poult. Sci. 42:295.

4. Burton, G. W. 1989. Antioxidant action of carotenoids. J. Nutr. 119:109.

5. Clark, T. H., Faustman, C., Chan, W. K. M., Furr, H. C. and Riesen, J. W. 1999. Canthaxanthin as an antioxidant in a liposome model system and in minced patties from rainbow trout. J. Food. Sci. 64:982.

6. El Boushy, A. R. and Raterink, R. 1987. Consumers prefer well oxy-carotenoids for egg yolk pigmentation. Proc. 4th European Symp. On quality of eggs and egg products, Doorwerth. The Netherlands. 269.

7. Fletcher, D. L. and Halloran, H. R. 1981. An evaluation of a commercially available marigold concentrate and paprika oleoresin on egg yolk pigmentation. Poultry Sci. 60:1846.

8. Franceschi, S., Bidoli, E., Vecchia, C., Talamini, R., D'Avanzo, B., and Negri, E. 1994. Tomatoes and risk of digestive-tract cancers. Int. J. Cancer. 59:181.

9. Gaziano, J. M. and Hennekens, C. H. 1993. The role of beta-carotene in the prevention of cardiovascular disease. New York Acad. Sciences, 691:148.

10. Landrum, J. T. and Bone, R. A. 2001. Lutein, zeaxanthin, and the macular pigment. Archives of Biochemistry and Biophysics. 385:28.

11. Mayne, S. T., Jannerich, D. Y., Greenwald, P., Chorost, S., Tucci, C., Zaman, M. B., Melamed, R., Kiely, M. and McKneally, M. E. 1994. Dietary $\beta$-carotene and lung cancer risk in U.S. nonsmokers. J. Natl. Cancer Inst. 86:33.

12. McDonald, R. E. and Hultin, H. O. 1987. Some characteristics of the enzymic lipid peroxidation systems in microsomal fraction of flounder muscle. J. Food Sci. 52:15.

13. Murakoshi, M., Nishino, H., Satomi, Y., Takayasu, J., Hasegawa, Y., Tokuda, H., Iwashima, A., Okuzumi, J., Kitano, H. and Iwasaki, R. 1992. 
Potent preventive action of a-carotene than by $\beta$ carotene against carcinogenesis: spontaneous liver carcinogenesis and promoting stage of lung and skin carcinogenesis in mice are suppressed more effectively by a-carotene than by $\beta$-carotene. Cancer Res. 52:6583.

14. Schiedt, K., Weiser, H. and Weber, S. 1987. Retention, distribution and excretion of H3-labelled canthaxanthin in laying hens including egg yolk pigmentation. In, thesis for the doctor technicae degree, Norwegian Institute of Technology, University of Trondheim, Norway. 75.

15. Seddon, J. M., Ajani, U. A., Sperduto, R. D., Hiller, R., Blair, N., Burton, T. C., Farber, M. D., Gragoudas, E. S., Haller, J., Miller, D. T., Yannuzzi, L. A. and Willett, W. C. 1994. Dietary carotenoids, viatmins A, C, and E, and advanced age-related macular degeneration. JAMA, 272:1413.

16. Sikder, A. C., Chowdhury, S. D., Rashid, M. H., Sarker, A. K., and Das, S. C. 1998. Use of dried carrot meat (DCM) in laying hen diet for egg yolk pigmentation. AJAS. 11:239.

17. Storebakken, T. and No, H. K. 1992. Pigmentation of rainbow trout. Aquaculture. 100:209.

18. Strieff, K. 1970. The carotenoids and the colour of egg yolks and of poultry. Proc. of the Symp. on The Vitamins and the Carotenoids in Animals Nutrition. Cracow. Poland. 33.

19. Yeum, K. J. 1996. Carotenoids: functions and recent research progress. J. Food Sci. Nutri. 1:256.

20. Yeum, K. J., Taylor, A., Tang. G., and Russel, R. M. 1995. Measurement of carotenoids, retinoids and tocopherols in human lenses. Invest. Ophthamol. Visual Sci. 36:2756.

21. Yin, M. C. and Faustman, C. 1993. Influence of temperature, $\mathrm{pH}$, and phospholipid composition upon the stability of myoglobin and phospholipid: A liposome model. J. Agric. Food Chem. 41:853.

22. Ziegler, R. 1991. Vegetables, fruits, and carotenoids and the risk of cancer. Am. J. Clin. Nutri., 53 (suppl):251S.

23. 남기홍. 2000. 양질의 계란 생산전략 ㅍ 계란내 용물의 질, 콜레스테롤 함량, 난황색, 난중조절, 유기란. 한국가금학회지. 27:133.

24. 이상호, 박철우, 박원석, 이영춘, 최의성, 하영래. 1997. Benxo[a]pyrene으로 유발한 mouse forestomach tumor 생성에 대한 astaxanthin 함유 난황의 효과. 한국농화학회지 40:490.

(접수일자 : 2003. 5. 29. / 채택일자 : 2003. 8. 28.) 
1 Week

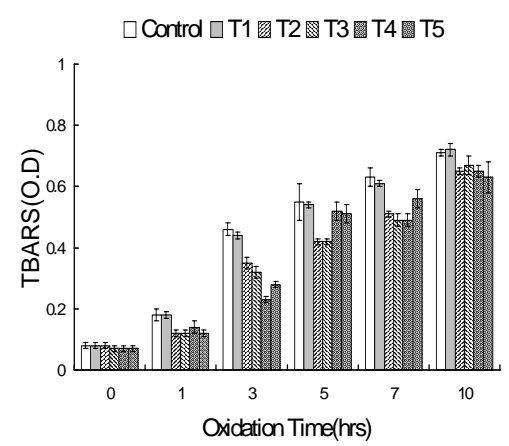

2 Weeks

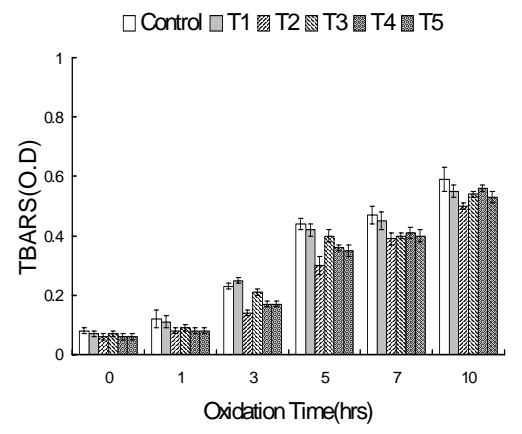

3 Weeks



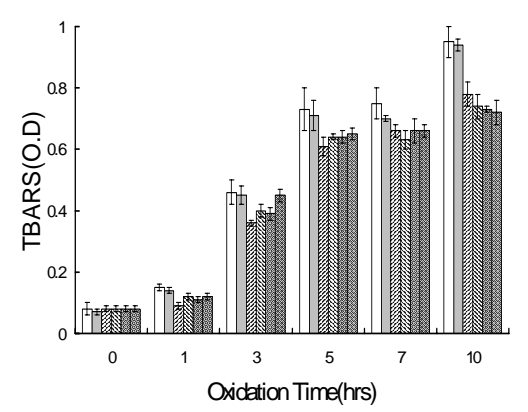

4 Weeks

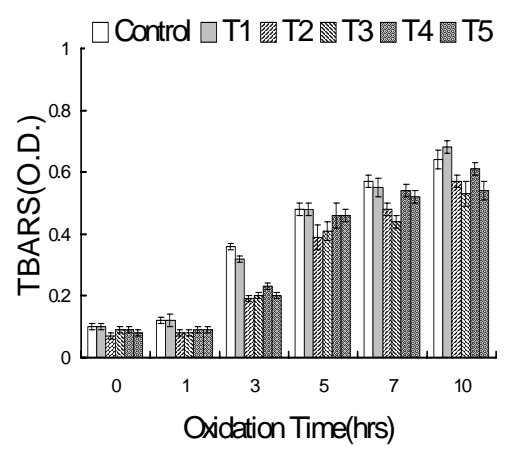

